\title{
Infectious DNA of the Human spumaretrovirus
}

\author{
Axel Rethwilm, Gerald Baunach, Kai-Olaf Netzer, Bernd Maurer, Bettina Borisch ${ }^{1}$ and Volker ter \\ Meulen \\ Institut für Virologie and ${ }^{1}$ Institut für Pathologie, Universität Würzburg, Versbacher Strasse 7, 8700 \\ Würzburg, FRG
}

Received December 14, 1989; Revised and Accepted January 11, 1990

\begin{abstract}
An infectious molecular clone (PHSRV) of the human Spumaretrovirus (HSRV) was constructed using viral DNA and CDNA clones. The infectivity of pHSRV was proven by transfection of cell cultures and subsequent infection of susceptible cultures with cell free transfection derived virus. pHSRV derived virus produced foamy virus typical cytopathic effects in susceptible cultures. Infected cells could be stained specifically with foamy virus antisera by means of indirect immunofluorescence. Radioimmunoprecipitation revealed the presence of characteristic HSRV structural proteins in pHSRV infected cultures. By cotransfection of pHSRV and an indicator plasmid it was found that pHSRV is able to transactivate the viral LTR. Viral transcripts were found to be approximately 200 bases longer in pHSRV infected cultures compared to wildtype infected cultures. This difference is most likely due to an insertion of DNA of non-viral origin in the U3 region of the 3'LTR of the infectious clone.
\end{abstract}

\section{INTRODUCTION}

Retroviruses have been subdivided into three major groups: oncoviruses, lentiviruses and spumaviruses (1). While oncoviruses and more recently lentiviruses have been characterized intensively there is only little knowledge on the biology of spumaviruses. Spumaviruses are widespread in wild and captive non-human primates, in bovines, and felines, and are belived to be nonpathogenic in their hosts (2). In contrast, in man spumavirus isolations are rare and have only been obtained from nasopharyngeal carcinoma cells originating from Tanzania (7) from cases of thyreoditis de Quervain $(3,4)$, from one case of myeloic leukemia (5) and one case of toxic encephalopathy (6). Serologic surveys based on indirect immunofluorescence indicated endemic areas in East Africa (8) and virus presence in Pacific Islands populations (9). But so far the pathogenic potential of spumaretroviral infections in humans is unrevealed (10).

Recently the genome organization of HSRV isolated from nasopharyngeal carcinoma cells has been described $(11,12)$. The genome length revealed $>11,000$ bases in its RNA form and includes gag, pol, and env genes, characteristic for all replication competent retroviruses $(11,12)$. Furthermore HSRV bears open reading frames (ORFs) in the central and 3'region of the genome, which are probably coding for gene products having regulatory functions similar to those described for human T-lymphotropic viruses (HTLVs) and human immunodeficiency viruses (HIVs) (13). Two of the three ORFs called bell and bel3 located between the env gene and the 3'LTR, revealed limited but significant sequence homologies to the HIV-2 tat and nef genes, respectively (14). Moreover, it was shown recently that transcription from the HSRV LTR is markedly enhanced in virus infected cells (15). To conduct more detailed studies on the molecular biology of HSRV we have constructed an infectious molecular clone. This plasmid will be invaluable in investigating the proposed regulatory genes of HSRV.

\section{MATERIALS AND METHODS}

Cells and virus

Baby hamster kidney cells (BHK-21) were obtained from Dr. D. Neumann-Haefelin (Freiburg, FRG), human glioblastoma cells U-251 MG from Dr. D.D. Bigner (Durham, USA), human hepatoma cells HEP G2 from Dr. H. Will (Munich, FRG), VeroA and primary human embryonic lung cells (HEL) from Dr. A. Pohl-Koppe (Würzburg, FRG). Cells were grown in modified Eagles medium supplemented with $5 \%$ fetal calf serum, glutamine and antibiotics. Wildtype HSRV infected HEL cells were a gift of Dr. R.M. Flügel (Heidelberg, FRG). Virus was first passaged on HEL cells and than adapted to different cell cultures by cocultivating recipient cells with a freeze/thaw lysate of infected HEL cells. For transmission of cell free virus supernatant from infected cultures was cleared by low speed centrifugation and passed through a $0.2 \mu \mathrm{m}$ filter (Millipore). Infection was carried out by incubating the cells with virus containing supernatant for one hour at $37^{\circ} \mathrm{C}$, washing once with medium and feeding with fresh medium. Titration of virus was done as described previously (16).

\section{Plasmids and DNA constructions}

The infectious clone pHSRV was constructed from viral DNA clones pHSRV-B-Cl1 (Cl1) and pHSRV-B52 (B52) and CDNA clone pHSRV-H-C55 (C55), which together represent the whole viral genome. Molecular cloning and nucleotide sequence analysis of the clones have already been described $(11,12,17)$. Cloning procedures were according to established methods (18), using restriction enzymes and DNA modifying enzymes from Boehringer-Mannheim and New England Biolabs. 


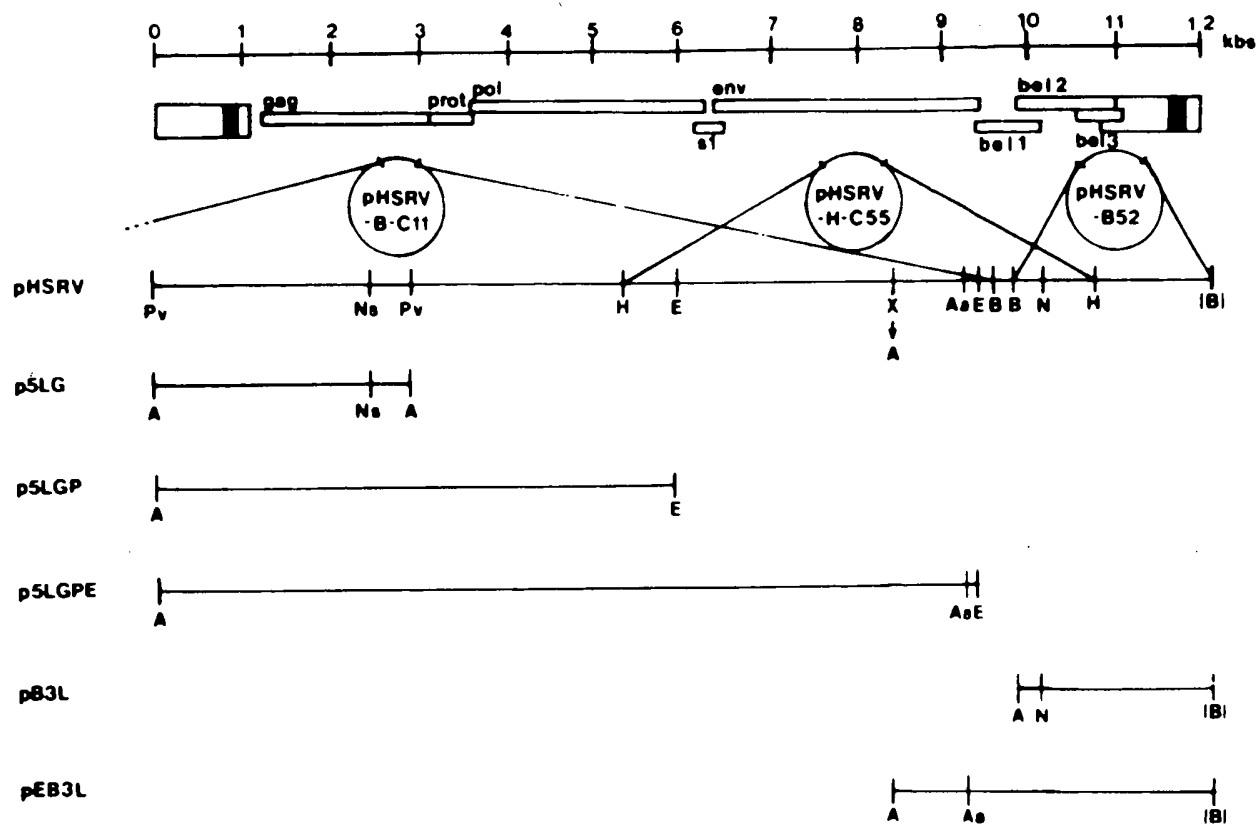

Figure 1: Genome organization of HSRV and cloning strategy of pHSRV (modified from (11) and(12). A (Asp718), Aa (AatII), B (BamHI), E (EcoRI), H (HindIII), $\mathrm{N}$ (Ncol), Ns (Nsil), Pv (PvuII), X (Xbal).

Oligonucleotide linkers were from New England Biolabs. All plasmid constructions were verified by restriction enzyme analysis. Molecular cloning of pHSRV cat which bears the HSRV 3'LTR 5 ' to the bacterial chloramphenicol acetyltransferase gene has been described recently (15).

\section{Transfection and CAT assay}

DNA was transfected into adherent cells as a $\mathrm{CaPO}_{4}$ coprecipitate (19). After overnight incubation at $37^{\circ} \mathrm{C}$ cells were shocked with $15 \%$ glycerol in transfection buffer for $1-2 \mathrm{~min}$. For CAT assays cells were harvested $48 \mathrm{hrs}$ after transfection and processed as described (20). CAT assays were performed with various amounts of protein as determined by a commercial protein assay (Biorad), $0.1 \mu \mathrm{Ci}{ }^{14} \mathrm{C}$-chloramphenicol (Amersham), and $1 \mathrm{mM}$ acetyl-CoA (Sigma) in 0.25M TRIS, pH8.0. Assays were incubated for $60 \mathrm{~min}$. at $37^{\circ} \mathrm{C}$.

\section{RNA extraction and Northern-blot hybridization}

RNA was extracted by the guanidinium-isothiocyanate method followed by centrifugation through a $\mathrm{CsCl}$ cushion (21). Poly $\mathrm{A}^{+}$RNA was selected on oligo (dT) cellulose (BoehringerMannheim). RNAs were run on formaldehyd containing $1 \%$ agarosegels and blotted onto gene screen plus nylon membranes (DuPont). Filters were prehybridized in $50 \%$ formamide, $5 \times$ SSC ( $1 \times$ SSC is $0.15 \mathrm{M} \mathrm{NaCl}$ and $0.015 \mathrm{M} \mathrm{Na}$-citrate, $\mathrm{pH} 7.0)$, $0.05 \mathrm{M} \mathrm{Na}_{2} \mathrm{HPO}_{4} / \mathrm{NaH}_{2} \mathrm{PO}_{4}(\mathrm{pH} 6.5), 5 \times \mathrm{BFP}(1 \times \mathrm{BFP}$ is $0.2 \mathrm{~g} / \mathrm{l}$ bovine serum albumin, $0.2 \mathrm{~g} / \mathrm{l}$ Ficoll 400 and $0.2 \mathrm{~g} / \mathrm{l}$ polyvinylpyrrolidon) and $0.5 \mathrm{~g} / \mathrm{l}$ t-RNA at $48^{\circ} \mathrm{C}$. Hybridization was carried out in the same buffer containing DNA probe and reduced concentrations of sodiumphosphate $(0.02 \mathrm{M})$ and $t-R N A$ $(0.05 \mathrm{~g} / \mathrm{l})$ at $48^{\circ} \mathrm{C}$. Filters were washed $3 \times 30 \mathrm{~min}$. in $0.5 \times \mathrm{SSC}$, $0.1 \%$ SDS at $75^{\circ} \mathrm{C}$, dried and exposed to DuPont Cronex films overnight at $-70^{\circ} \mathrm{C}$ using an intensifying screen. Probes were labeled with $\alpha^{32}$ P-dCTP (Amersham) as described (22) to a specific activity of $5 \times 108 \mathrm{cpm} / \mu \mathrm{g}$.
Table 1: Appearance of foamy virus c.p.e. in cultures infected with wildtype virus or transfected with plasmid DNA

\begin{tabular}{|c|c|c|c|}
\hline & BHK-2I & U251-MG & VeroA \\
\hline HSRV $_{w t}$ & $\begin{array}{l}\text { d } 2+ \\
\text { d } 7+++\end{array}$ & $\begin{array}{l}\text { d } 1+ \\
\text { d } 9++\end{array}$ & $\begin{array}{l}\text { d } 2+ \\
\text { d } 9+\end{array}$ \\
\hline pHSRV & $\begin{array}{l}\text { d } 4+ \\
\text { d } 7+++\end{array}$ & $\begin{array}{l}\text { d } 8+ \\
\text { d14 +++ }\end{array}$ & $\begin{array}{l}\text { d10 + } \\
\text { d30 + }\end{array}$ \\
\hline pSLPGE/pEB3L & $\begin{array}{l}\text { d } 6+ \\
\text { d10 ++ }\end{array}$ & $\begin{array}{l}\text { d14 }+ \\
\text { d20 +++ }\end{array}$ & n.d. \\
\hline p5LPGE & n.d. & d21 - & $\mathrm{dl} 4-$ \\
\hline pBR322 & d15 - & d21 - & n.d. \\
\hline
\end{tabular}

Cells were infected with cell free wildtype virus or were transfected as indicated and observed for multinucleated giant cell c.p.e. Given are the days after infection/transfection with minimal c.p.e. $(+<10 \%$ multinucleated cells $)$, medium c.p.e. $(++=10-50 \%$ multinucleated cells), and maximal c.p.e. $(+++$ $=50-100 \%$ multinucleated cells). $-=$ no c.p.e. visible, n.d. not done.

Indirect immunofluorescence (IFA) and radioimmunoprecipitation (RIPA)

Cells were grown on coverslips, washed in PBS, dried, fixed in cold acetone and IFA was performed as described (23), using HSRV positive and negative human sera at a 1:10 dilution and FITC conjugated anti human IgG.(Dakopatts). RIPA was essentially done as described recently (24). Briefly, cultures were metabolically labeled with ${ }^{35} \mathrm{~S}$-methionine for $16 \mathrm{hrs}$ at $37^{\circ} \mathrm{C}$. Cells were lysed in RIPA detergent buffer (0.02M TRIS ( $\mathrm{pH} 7.4)$, $0.3 \mathrm{M} \mathrm{NaCl}, 1 \%$ Triton $\mathrm{X}-100,1 \%$ desoxycholate, $0.1 \%$ SDS, $0.001 \mathrm{M}$ phenylmethyl-sulfonylfluoride), and lysates were cleared by brief ultracentrifugation. $50 \mu$ l of lysate were reacted with $2.5 \mu \mathrm{l}$ of serum at $4^{\circ} \mathrm{C}$ for $60 \mathrm{~min}$. Immuncomplexes were precipitated with proteinA-sepharose beads (Pharmacia), washed with RIPA detergent buffer and resolved on $7.5 \%$ polyacrylamid-SDS gels (25). Gels were fixed, washed in fluorographic reagent (Amersham), dried and exposed to X-ray films at $-70^{\circ} \mathrm{C}$. 

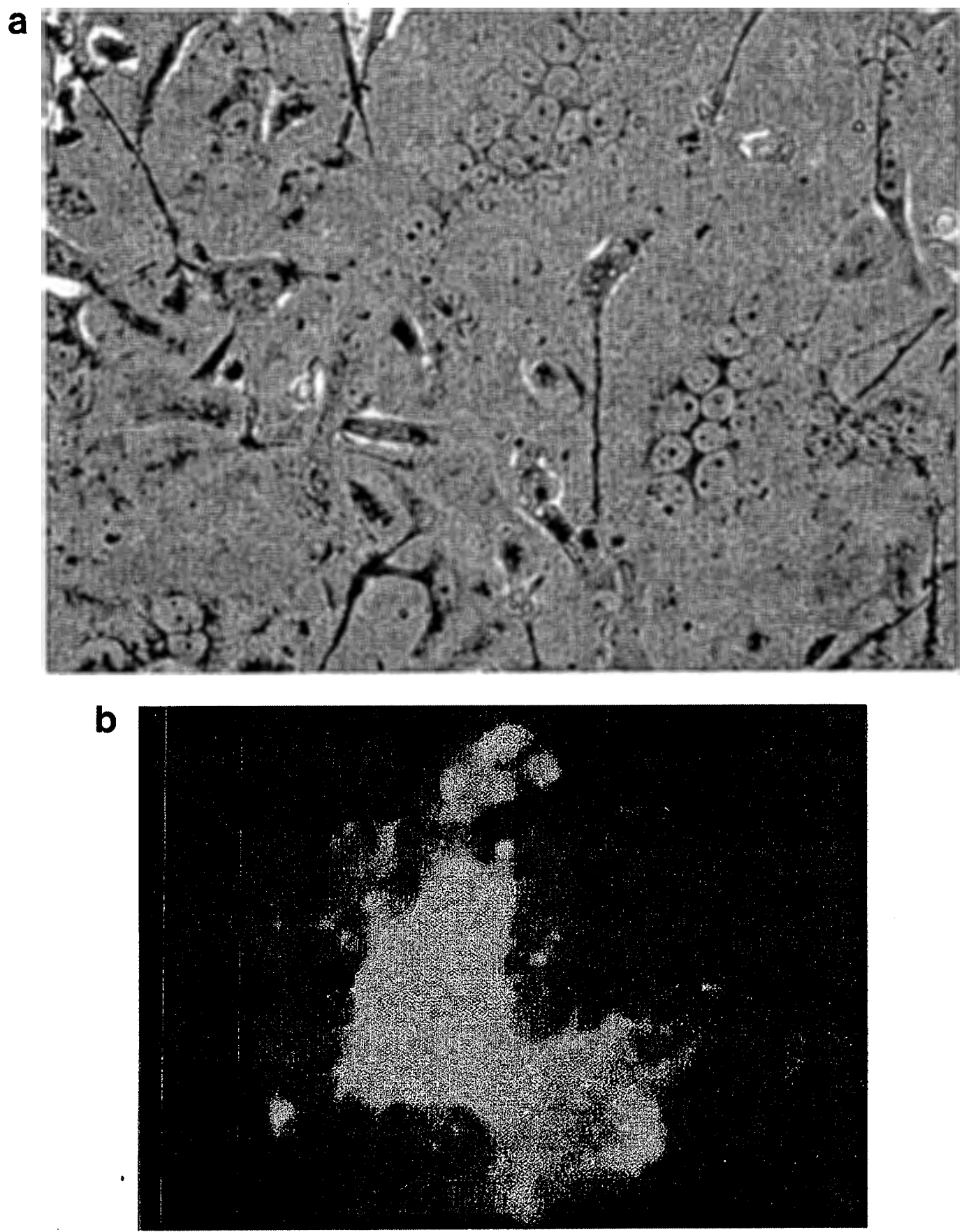

Figure 2: (a) Multinucleated giant cell c.p.e. in U251-MG glioblastoma cells infected with pHSRV derived cell free virus. (b) Indirect immunofluorescence of pHSRV infected hepatoma cell line Hep G2 using a human $\alpha$ HSRV senum.

\section{RESULTS}

\section{Construction of pHSRV}

The infectious plasmid pHSRV was constructed using the three viral clones C11, C55 and B52. Plasmid C11 harbours a 15.4 kb BamHI insert where viral genes are organized in the order: 5'- $\Delta$ bel1-env-S1- $\Delta$ pol-5'LTR-gag-pol-S1-env- $\Delta$ bel1-3'. Viral genes in the $5.5 \mathrm{~kb}$ HindIII insert of C55 appear in the order:5'- $\Delta$ pol-S1-env-bel1-bel2- $\Delta$ bel3-3', and in the $2.2 \mathrm{~kb}$ insert of B52 in the order:5'- $\Delta$ bel1-bel2-bel3-3'LTR-3'. Thus, the whole viral genome of HSRV is represented by these molecular clones. The strategy for generation of pHSRV is outlined in Fig.1. In general, two overlapping viral clones were constructed by stepwise addition of viral DNA fragments using enzymes that cut only once or twice in the portion to be cloned. Following this principle, Asp718 linkers were added to a 3.0 


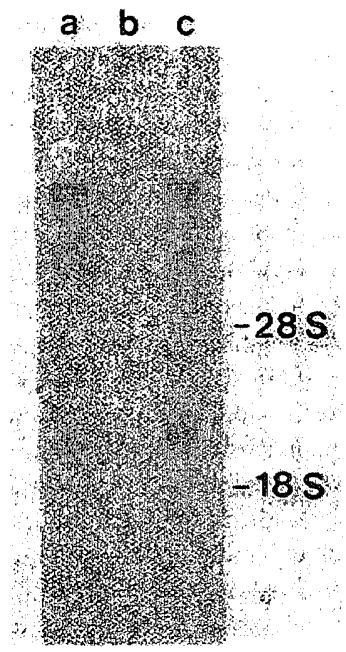

Figure 3: Northern-blot of poly $\mathrm{A}^{+}$RNA from wildtype infected (a), uninfected (b), and BHK21 cells infected with pHSRV derived cell free virus (c). RNAs were hybridized to ${ }^{32} \mathrm{P}$-labeled pHSRV DNA.

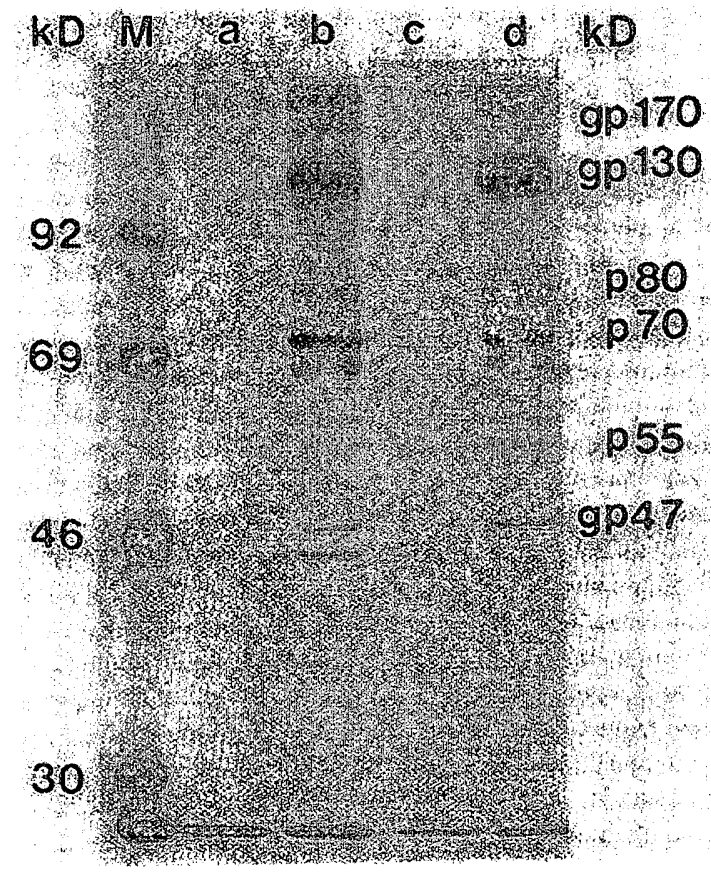

Figure 4: SDS-gelelectrophoresis of protein precipitated from wildtype (a.b) and pHSRV (c,d) infected BHK21 cells using HSRV negative $(a, c)$ and HSRV positive (b,d) human serum.

kb fragment of $\mathrm{C} 11$, running from a Pvull site in the flanking sequence 43bp 5' to the 5' LTR to a Pvull site in the gag ORF, and the fragment was cloned into pUC19 vector, leading to p5LG. A $3.6 \mathrm{~kb} \mathrm{Nsil/EcoRI} \mathrm{fragment} \mathrm{from} \mathrm{Cll}$ was inserted into Nsil/EcoRI cut p5LG, leading to p5LGP. Plasmid p5LGPE was derived by inserting a $3.5 \mathrm{~kb}$ EcoRI fragment of C 55 into EcoRI cut p5LGP. The $3^{\prime}$ third of the viral genome was reconstituted by (i) modifying a single BamHI site of $\mathrm{B} 52$ and a single Xbal site of C55, respectively, into Asp718 sites and (ii) inserting a

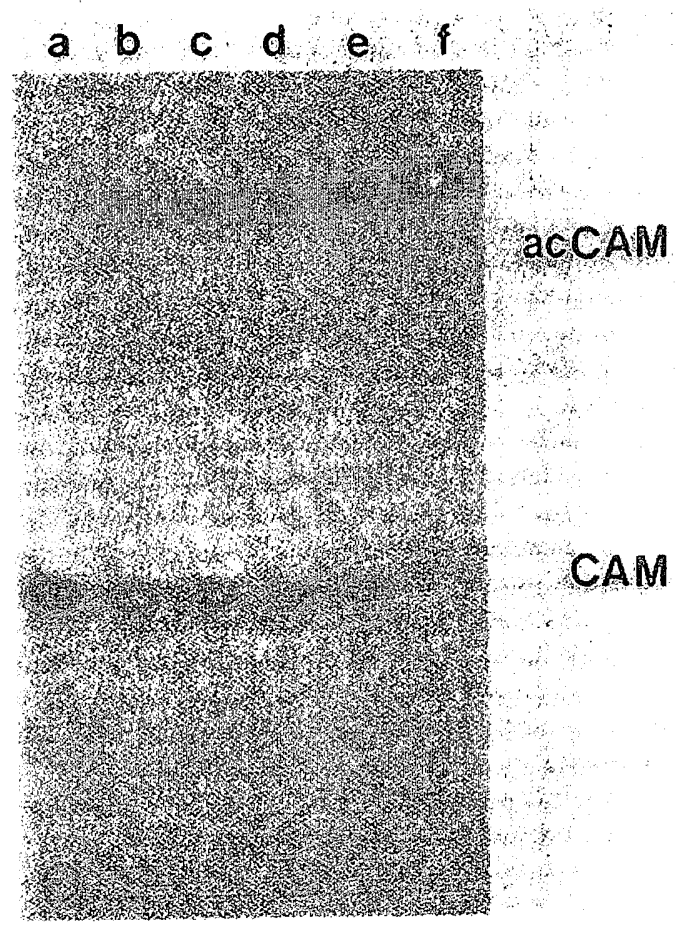

Figure 5: CAT assay of lysates from BHK-21 cells transfected with pHSRVcat/pBR322 (a), pHSRVcat/pHSRV (b-e), pSV2cat/pBR322 (f). Protein amounts in the reactions and conversion rates for acetylated chloramphenicol (ac CAM) were (a) $250 \mu \mathrm{g} / 1 \%$, (b) $25 \mu \mathrm{g} / 21 \%$, (c) $50 \mu \mathrm{g} / 37 \%$, (d) $75 \mu \mathrm{g} / 45 \%$ (e) $100 \mu \mathrm{g} / 56 \%$, and (I) $100 \mu \mathrm{g} / 97 \%$.

$1.7 \mathrm{~kb}$ Asp $718 / \mathrm{Ncol}$ fragment of the latter into the respective sites of the first, leading to pEB3L. Plasmids p5LGPE and pEB3L overlap by $1.0 \mathrm{~kb}$ and have a single AatII site in the overlap. Plasmid pHSRV was constructed by cloning the $9.3 \mathrm{~kb}$ Asp718/AatII fragment of p5LGPE into Asp718/AatII cut pEB3L. Restriction enzyme mapping revealed all restriction enzyme sites used during the cloning procedure were unchanged in PHSRV (data not shown).

\section{Transfection experiments}

BHK-21, U-251 MG and Vero A cells were transfected with 20 $\mu \mathrm{g}$ of DNA. DNAs used for transfection were pHSRV $(20 \mu \mathrm{g})$, p5LGPE $(20 \mu \mathrm{g})$, p5LGPE/pEB3L $(10 \mu \mathrm{g} / 10 \mu \mathrm{g})$, and pBR322 $(20 \mu \mathrm{g})$. Parallel cultures were infected with cell free wildtype virus at a multiplicity of infection (m.o.i.) of 0.1 . Cultures were passaged and examined for foamy virus typical cytopathic effect (c.p.e.) daily by light microscopy. The result of a typical experiment is shown in Tab.1. In wildtype infected cells multinucleated giant cell c.p.e. first appeared after one (U-25I MG) or two (BHK-21 and VeroA) days and was maximal within 7-9 days. In cultures transfected with pHSRV c.p.e. occurred 4-10 days post transfection and in cultures transfected with the two overlapping plasmids p5LGPE and pEB3L 6-14 days after transfection. Once c.p.e. had become visible in the transfected cultures there was no delay in the progression of infection until c.p.e. reached maximal levels relative to wildtype infected cultures. No c.p.e. was observed in cells transfected with p5LGPE only or with pBR322 even after 3 weeks of cultivation. All following experiments were carried out with cell free transfection derived vinus. As shown in Fig.2a cells infected with 
cell free supernatants from pHSRV transfected cultures form foamy virus typical giant cell c.p.e. Furthermore, cells infected with PHSRV derived virus could specifically be stained with HSRV positive serum by IFA. Using a human $\alpha$ HSRV serum pHSRV infected HepG2 cells show a foamy virus specific nuclear as well as cytoplasmic fluorescence (Fig.2b).

\section{Analysis of viral transcripts}

Poly $\mathrm{A}^{+}$RNA from pHSRV and wild type infected cultures was run on denaturing gels, blotted and hybridized to ${ }^{32} \mathrm{P}$-labeled pHSRV DNA. As shown in Fig. 3 three bands were detected in both RNA preparations (compare lanes a and $c$ ). In lane a the smallest band corresponds to RNA of ca. $2.5 \mathrm{~kb}$, the middle band to RNA of ca. $6.3 \mathrm{~kb}$ and the largest band to ca. $11.2 \mathrm{~kb}$ RNA. While the pattern of HSRV transcripts was clearly the same in pHSRV and wildtype infected cultures, the pHSRV infected cultures yield transcripts slightly longer (ca. $0.2 \mathrm{~kb}$ ) than the wildtype infected cultures.

\section{Analysis of viral proteins}

To test whether differences found in viral transcript lengths between pHSRV and wildtype virus resulted in viral proteins of different molecular weights we performed radioimmunoprecipitation assays. Proteins from lysates of infected BHK-21 cultures were precipitated with HSRV positive human sera detecting the main structural viral proteins. The precipitates were analysed on SDS polyacrylamide gels. As shown in Fig.4 the relative mobility of precipitated proteins were the same in pHSRV and wildtype infected cultures (compare lanes $b$ and d). Proteins identified in both lysates were the env related glycoproteins gp170, gp130 and gp47 (24). Further virus specific but so far uncharacterized proteins detected in both preparations were of the apparent molecular weight of 80,70 , and $55 \mathrm{kD}$.

\section{Transactivation assay}

Since transcription of a reporter gene under control of the HSRV LTR is markedly enhanced in HSRV infected cells compared to uninfected cells (15), we tested whether cotransfection of pHSRV and an indicator plasmid leads to transactivation. As an indicator plasmid we used pHSRVcat, a plasmid harbouring the $3^{\prime}$ LTR of HSRV 5' to the cat gene. Fig.5 shows that pHSRVcat is silent upon cotransfection with pBR322 DNA assaying 250 $\mu \mathrm{g}$ of protein from prepared lysates (lane a). In contrast, acetylation of chloramphenicol could clearly be observed in assays with increasing protein amounts of lysates prepared from cultures cotransfected with pHSRV (lane b: $25 \mu \mathrm{g}$, lane c: $50 \mu \mathrm{g}$, lane d: $75 \mu \mathrm{g}$, lane e: $100 \mu \mathrm{g}$ ). As positive control $100 \mu \mathrm{g}$ protein of a lysate from a culture transfected with pSV2cat were run (lane f).

\section{DISCUSSION}

Here we have described the construction and characterization of an infectious molecular clone of the human spumaretrovirus. Transfection of susceptible cultures with the construct pHSRV leads to cell free infectious viral particles as does transfection with the two overlapping plasmids p5LGPE and pEB3L. pHSRV derived virus was found to be identical to wildtype virus with respect to c.p.e. formation, apparent molecular weight of viral proteins and transactivation of the viral LTR. The only differences found were in the lengths of viral transcripts. In both RNA preparations three predominant viral transcripts were found, corresponding most likely to genomic RNA, spliced env message and probably double spliced messages for the regulatory proteins as described for related retroviruses $(26,27)$. pHSRV messages were ca. $0.2 \mathrm{~kb}$ longer than wildtype messages. Interestingly, 5'LTR and 3'LTR of pHSRV differ by a stretch of 158 nucleotides flanked by a 4 bp repeat that is present in the U3 region (at nucleotide position 11336 of pHSRV) of the $3^{\prime} \mathrm{LTR}$ (derived from clone B52) but missing in the 5'LTR (derived from clone $\mathrm{C} 11)(11,12)$. Since all retroviral transcripts terminate at the R-U5 border of the 3'LTR one would expect, that the 158 nucleotide stretch is present in all pHSRV derived viral transcripts. It has been speculated that the $158 \mathrm{bp}$ stretch is an insertion of non-viral origin in the 3' LTR of clone B52 (12). The ca. $0.2 \mathrm{~kb}$ smaller wildtype transcripts found in the present study strongly support this view. Whether this insertion will influence the biological properties of the virus remains to be elucidated. Obviously, it does not interfer with viral replication.

HSRV shares some striking features with the pathogenic human retroviruses especially of the lentiviral subgroup (13). Like HIV HSRV uses tRNA-lys as primer for first strand CDNA synthesis (12), has an extraordinary long ORF for heavily glycosylated env proteins $(12,24)$, and encodes for several additional gene products to gag, pol and env $(11,12,13)$. One of which probably represents a viral transactivator (15). The availability of an infectious molecular clone for HSRV will allow to characterize the function of these genes in relation to the function of the regulatory genes of HIV and HTLV.

\section{ACKNOWLEDGMENT}

We thank Cornelia Römmelt for expert technical assistance and Helga Kriesinger for typing the manuscript. We are indebted to Ivan Horak for critical reading the manuscript. This work was supported by Bundesministerium für Forschung und Technologie and by Deutsche Forschungsgemeinschaft.

\section{REFERENCES}

1. Weiss, R.A., Teich, N., Varmus, H. and Coffin, J. (1984). RNA Tumor Viruses. Cold Spring Harbor Laboratory Press, Cold Spring Harbor.

2. Swack, N.S. (1981) CRC Handbook Series in Zoonoses, Vol. II, 282-288

3. Stancek, D., Stancekova, M., Janotta, M., Huilica, P. and Orevec, D. (1975). Med. Microbiol. Immunol. 161, 133-144

4. Werner, J. and Gelderblom, H (1979) Lancet ii, 258-259

5. Young, D., Samuels, J. and Clarke, J.K. (1973). Arch. Gesamte Vinusforsch. 42, 228-234

6. Cameron, K.R., Birchall, S.M. and Moses, M.A. (1978). Lancet ii, 796

7. Achong, G., Mansell, P.W.A., Epstein, M.A. and Clifford, P. (1971). J. Natl. Cancer Inst. 42, 299-307

8. Muller, H.K., Ball, G., Epstein, M.A., Achong, B.G., Lenoir, G. and Levin, A. (1980). J. Gen. Virol. 47, 399-406

9. Loh, P.C., Matsumura, F. and Mizumoto, C. (1980). Intervirology 13, 87-90

10. Weiss, R.A. (1988) Nature 333, 497-490.

11. Flügel, R.M., Rethwilm, A., Maurer, B. and Darai, (1987). EMBO J. 6, 2077-2084

12. Maurer, B., Bannert, H., Darai, G. and Flügel, R.M. (1988). J. Virol. 62, $1590-1597$

13. Maurer, B. and Flügel, R.M. (1988). AIDS Res. Human Retrovir. 4, $467-473$

14. Maurer, B. and Flügel, R.M. (1987). FEBS Lett. 222, 286-288

15. Rethwilm, A., Mori, K., Maurer, B. and ter Meulen, V. (1990). Virology (in press)

16. Neumann-Haefelin, D., Rethwilm, A., Bauer, G., Gudat, F. and zur Hausen, H. (1983). Med. Microbiol. Immunol. 172, 75-86

17. Rethwilm, A., Darai, G., Rösen, A., Maurer, B. and Flügel, R.M. (1987). Gene 59, 19-28

18. Maniatis, T., Fritsch, E.F. and Sambrook, J. (1982). Molecular Cloning: 


\section{Nucleic Acids Research}

A Laboratory Manual. Cold Spring Harbor Laboratory Press, Cold Spring Harbor.

19. Graham, F. and von der Eb, A. (1973). Virology 52, 456-457

20. Sorman, C.M., (1982). Mol. Cell. Biol. 2, 1044-1051

21. Chirgwin, J.M. (1979). Biochem. 18, 5294-5299

22. Feinberg, A.P. and Vogelstein, B. (1984). Anal. Biochem. 137, 266-267

23. Henle, G. and Henle, W. (1966). J. Bact. 9I, 1248-1256

24. Netzer, K.-O., Rethwilm, A., Maurer, B. and ter Meulen, V. (1990). submitted

25. Laemmli, U.K. (1970). Nature 227, 680-685

26. Seiki, M., Hikikoshi, A., Taniguchi, T. and Yoshida, M. (1985). Science $228,1532-1534$

27. Muesing, M.A., Smith, D.H., Cabradilla, C.D., Benton, C.V., Lashy, C.A and Capon, D.J. (1985). Nature 313, 450-458 